\title{
RECENZJE
}

\section{Pułapki na mężczyzn i genderowe uniki}

Dawniej bycie mężczyzną wydawało się czynnością niekłopotliwą, a zwłaszcza nieproblematyczną: po prostu się nim było i korzystało się z przywilejów (raczej) wynikających z tego faktu. Bycie mężczyzną dzisiaj, w czasach zdominowanych, przynajmniej na poziomie głównego dyskursu, na kwestiach kobiecości, okazuje się i niełatwe, i nieproste. Kobiecość, kobietę kulturową, kobietę społeczną analizuje się w antropologii ostatnich trzydziestu lat nieustannie, szuka się maskulinistycznych narzędzi tortur, jakimi kobiety zostały ujarzmione i zdominowane w kulturze, ale i w realnym życiu w minionych stuleciach. Równocześnie temat męski ześlizgnął się ze zbocza antropologicznej nauki; współczesny mężczyzna funkcjonuje jako echo dawnych ujęć. Można zapytać: czy współczesny mężczyzna jest taki jak jego poprzednik z epoki fin de sciele'u, renesansu, hellenizmu, czy może jest kimś innym niż jego antenaci? I czy można mówić o współczesnym mężczyźnie, czy raczej o różnych wzorcach męskich wypełniających różnorodność globalnego tygla? To pytania, wobec których stajemy bezradnie, bo heteroseksualna męskość przestała być tematem modnym, a w istocie wartym antropologicznego wysiłku badawczego w dzisiejszej antropologii kulturowej. I jeszcze taka kwestia: jeśli badania genderowe mają zajmować się różnicą między kobietami a mężczyznami, to czy nie powinny przykładać jednakowej miary do obu stron relacji? Oczywiście, że powinny. Dlaczego zatem tego nie robią?

Książka włoskiego badacza kultury współczesnej Franco La Cecli ten problem stawia w centrum dyskusji. Na ile intensywnie problematyka męskiej tożsamości tkwi w dzisiejszej debacie antropologicznej i genderowej, a na ile jest wypełniana stereotypami kulturowymi, bądź (co gorsza) medialnymi, zastępującymi faktyczne stany rzeczy. La Cecla twierdzi, że dotychczasowy antropologiczny 
dyskurs płciowy doprowadził do swoistej wojny; w tej wojnie stroną atakujaccą jest feminizm i post-feminizm, spychając problem męskiego poczucia dumy i męskich pragnień do antropologicznego kąta. Sądzi, że w istocie gender studies nie traktują o różnicy płci, a prawie wyłącznie o kobiecie i kobiecości. I pisze z ironią: „O męskości wolno pisać pod warunkiem, że się nikogo nie urazi i że się nie mówi z perspektywy od środka. (...) Stąd już tylko krok do uogólnienia, że «wszyscy mężczyźni to dranie», jakby badania nad męską tożsamością płciową nie mogły dorosnąć i dla uzyskania akceptacji musiały się chować za matczyną (lub transseksualistów) spódnicą. Nadal przeważa postawa «przepraszam, że mówię o mężczyznach»" (s. 35).

Dyskusja o różnicy płciowej zbyt mocno została w ostatnich dekadach wpisana w kontekst polityczny; została zdominowana wyrównywaniem krzywd (kobiecych) za stulecia nierówności i wypchnięcia kobiet z głównej areny publicznej. To upolitycznienie debaty sprawia, że z wielkim trudem jesteśmy dziś w stanie docierać do „archeologii płciowych”, bo chociaż większość badaczy zrywa z esencjalizmem antropologicznym (uchwytywaniem płci w kontekście jakiś trwałych i nieusuwalnych cech wyznaczających tożsamość), niemniej założenie istnienia podstawy męskiej i kobiecej tożsamości nie wydaje się absurdalne. Owe archeologie płci nie przeczą tezie o płynności tożsamości, wszak, jak pisze włoski badacz, płynność kształtuje się dzięki temu, że istnieją antypody płciowe, między którymi zachodzą procesy kształtowania, w przeciwnym bowiem razie rozpłynęlibyśmy się w jakiejś hipotetycznej „trzeciej płci” postulowanej przez manifesty post-feminizmu albo w całkowitej nieokreśloności. Franco La Cecla stawia zarzut, że badania genderowe od początku (czyli od lat 70.) pomijały z powodów ideologicznych i politycznych aspekt tożsamości męskiej: „Do tego stopnia, że womens's studies praktycznie utożsamiano z gender studies. Większość esejów i badań z tego zakresu poświęcono kształtowaniu się kobiecej tożsamości w tej czy owej grupie, przyjmując często optykę, która podkreślała sytuację podporządkowania, wykorzystywania i cenzurowania kobiet" (s. 42). Wskutek tego męskość jako problem badawczy i kwestia rzeczywista jest dzisiaj trywializowana. Ale to nie jest najgorszy skutek stanu debaty genderowej, bo tak naprawdę doprowadziło to do „pogubienia” i „podzielenia” nas, współczesnych kobiet i mężczyzn, co zdaniem włoskiego antropologa wywołało kryzys - nie męskości, lecz raczej relacji między męskim i żeńskim, albowiem „sprawy związane z płcią, tożsamością płciową oraz kondycją męską, kobiecą, gejowską czy transgenderową niewiele miały wspólnego z badaniami naukowymi i ich praktycznym zastosowaniem" (s. 27). Wystarczy uświadomić sobie fakt (jak utrzymuje La Cecla), że głównym strażnikiem politycznej poprawności jest dziś „kobieta”, która aspiruje do bycia jedynym mierniczym wyznaczającym zakres męskości, i która narzuca normy i karcące reguły. Trudno się zatem dziwić, że wielu współczesnych mężczyzn ucieka się bądź do strategii 
bycia szorstkim (maczyzm), bądź do strategii niepewności i uległości (syndrom Piotrusia Pana). Po prostu, pod wpływem procesów emancypacji kobiet mężczyźni utracili pewność siebie; ale to może rodzić frustracje, które nie mogąc się manifestować ze względu na polityczną poprawność, odkładają się w psychice mężczyzn; taki mechanizm może doprowadzić do wybuchów niekontrolowanej i reaktywnej agresji, jak w tych przypadkach męskiej przemocy wobec zbyt wyemancypowanych młodych Tunezyjek, które przytacza La Cecla. Otóż za pewnik uznaliśmy, że wszystko się zmienia, że zmienia się kultura, kobiety się uniezależniają wobec wzorców tradycjonalizmu, i że mężczyźni zmieniają się również - z łatwością akceptując zmiany. Jednak to ostatnie przekonanie jest zaledwie mglistą hipotezą (lub pobożnym życzeniem), która powinna być dopiero gruntownie zbadana.

Z tego opisu ogólnej sytuacji kulturowej wynika postulat autora, aby ponownie przyjrzeć się i zbadać bez uprzedzeń kondycję współczesnego mężczyzny. Jego książka zawiera ogólne konstatacje, które autor traktuje jako zaproszenie do dyskusji, a nie ostatecznie udokumentowane badawczo tezy. Trudność związana z budowaniem męskiej tożsamości i odpowiadającej jej narracji kulturowej polega na tym, ze ten proces jest obarczony większym wysiłkiem niż w przypadku tożsamości kobiecej; w męskiej tożsamości tkwi strukturalny (zatem trudny do wykorzenienia) składnik niezadowolenia i niepewności, który należy przynajmniej poskromić; dlatego to mężczyzna bardziej niż kobieta potrzebuje osiągnięć, aby potwierdzić własne poczucie wartości, jak utrzymuje za Margaret Mead autor; co bynajmniej nie oznacza, że mężczyzna chce za wszelką cenę prześcignąć kobietę pod względem prestiżu. O tej niepewności i wyjściowej nieokreśloności męskiej tożsamości La Cecla pisze w nieco patetycznym stylu tak oto: „(..) mężczyzna niesie w sobie ranę, która nie może się zabliźnić, ranę tożsamości nieostrej, płynnej (flou), która musi znaleźć swoje kontury i ramy, i która przede wszystkim sama siebie poszukuje" (s. 122). To pokazuje wysiłek, który wiąże się z usytuowaniem mężczyzny w paradygmacie kulturowym: męskość jest konstytuowana poprzez redukcję cech czy aspektów kojarzonych z kobiecością ${ }^{1}$, dlatego mężczyźnie nie wolno przywiązywać tak wielkiej wagi do ciała, jak czynią to kobiety. Ale czy dzisiaj takie twierdzenie pozostaje aktualne? La Cecla twierdzi, że właśnie dlatego, że nie jest to oczywiste, należy zbadać współczesny męski sposób patrzenia na własne ciało, a w pewnym sensie przedefiniować go.

W jakiejś mierze włoski badacz chce, zmierzając tropem Foucaulta i Illicha, „odpłciowić” historię tożsamości i uniknąć w tej debacie narzucanego na siłę kierunku powszechnej homogenizacji lekceważącej różnice kulturowe, społeczne, religijne, i w istocie płciowe (wzorzec uniseksualności), i osiągnąć pole bezstronnej

1 „Tożsamość jest formą ascezy i cięcia wielu cech, a jej cząstkowość przynosi zadośćuczynienie w postaci własnej tajemnicy, którą uczymy się zgłębiać, lecz której nie wypowiadamy" (s. 17). 
rozmowy antropologicznej, nie wykluczającej a priori pojęcia różnicy. To oznacza konieczność zapewnienia męskiej tożsamości ochrony przed nową „społeczną eugeniką", czyli jej fundatorami - ruchami feministycznymi, post-feminizmem, kulturą queer i transgender, które chcą wyleczyć męskość z jej atrybutów. I nie jest to w żadnej mierze wezwanie do jakiejś męskiej wojennej reakcji, by przywrócić dawny patriarchalny stan; przeciwnie, La Cecla mówi o nowej kulturze, która byłaby prawdziwie otwarta, naprawdę inkluzywna, a nie stygmatyzująca - na przykład nieśmiałego homoseksualistę, który nie chce naśladować kobiecości. Nie powinno zatem dziwić, że włoski antropolog zapraszając do nowej dyskusji, prowadzonej bez tez przyjętych z góry, wraca do tego, co wydaje się powrotem do dawnych ujęć: „Odkryjmy na nowo męską ekspresję z całym jej bogactwem i wahaniem, odzyskajmy na nowo zakłopotanie, nieśmiałość, odwagę, by się zalecać, radzić sobie wśród mężczyzn, jak i wśród kobiet. Wszystkie te rzeczy są częścią obyczajowości męskiej nie jako przebranie, lecz jako znajomość siebie" (s. 165). Stawką jest archeologia męskiej tożsamości, „która jest dla nas bardzo ważna, jeśli chcemy zrozumieć, z jakich konstrukcji, jakich strojów i jakich ideologii jesteśmy dziś zbudowani w naszej męskiej tożsamości" (s. 165).

Książka La Cecli nie jest bynajmniej „wprowadzeniem” do antropologii mężczyzny, pozostaje jednak inspirującym „zaproszeniem” do niej.

Franco La Cecla, Szorstkim być. Antropologia mężczyzny, przeł. Hanna Serkowska, Wydawnictwo Sic!, Warszawa 2014, ss. 187. 